\title{
Chronic Interleukin-1 $\beta$ Expression in Mouse Brain Leads to Leukocyte Infiltration and Neutrophil-Independent Blood- Brain Barrier Permeability without Overt Neurodegeneration
}

\author{
Solomon S. Shaftel, ${ }^{1}$ Thaddeus J. Carlson, ${ }^{2}$ John A. Olschowka, ${ }^{1}$ Stephanos Kyrkanides, ${ }^{1,3}$ Sarah B. Matousek, ${ }^{1}$ and \\ M. Kerry 0’Banion ${ }^{1,4}$ \\ Departments of ${ }^{1}$ Neurobiology and Anatomy, ${ }^{2}$ Microbiology and Immunology, ${ }^{3}$ Dentistry, and ${ }^{4}$ Neurology, University of Rochester School of Medicine and \\ Dentistry, Rochester, New York 14642
}

\begin{abstract}
The proinflammatory cytokine interleukin- $1 \beta$ (IL-1 $\beta$ ) plays a significant role in leukocyte recruitment to the CNS. Although acute effects of IL- $1 \beta$ signaling in the mouse brain have been well described, studies elucidating the downstream effects of sustained upregulation have been lacking. Using the recently described IL-1 $\beta^{\mathrm{XAT}}$ transgenic mouse model, we triggered sustained unilateral hippocampal overexpression of IL- $1 \beta$. Transgene induction led to blood- brain barrier leakage, induction of MCP-1 (monocyte chemoattractant protein 1 ) (CCL2), ICAM-1 (intercellular adhesion molecule 1), and dramatic infiltration of CD45-positive leukocytes comprised of neutrophils, T-cells, macrophages, and dendritic cells. Despite prolonged cellular infiltration of the hippocampus, there was no evidence of neuronal degeneration. Surprisingly, neutrophils were observed in the hippocampal parenchyma as late as 1 year after transgene induction. Their presence was coincident with upregulation of the potent neutrophil chemotactic chemokines KC (keratinocyte-derived chemokine) (CXCL1) and MIP-2 (macrophage inflammatory protein 2) (CXCL2). Knock-out of their sole receptor CXCR2 abrogated neutrophil infiltration but failed to reduce leakage of the blood- brain barrier.
\end{abstract}

Key words: interleukin-1 $\beta$; blood-brain barrier; CXCR2; hippocampus; neurotoxicity; neutrophils

\section{Introduction}

Under normal physiological conditions, the mammalian CNS contains relatively few leukocytes (Ransohoff et al., 2003). However, this changes after insults to the CNS such as ischemia, infection, and traumatic brain injury (Del Rio et al., 2001; Emerich et al., 2002; Morganti-Kossmann et al., 2002). The proinflammatory cytokine interleukin-1 $\beta$ (IL-1 $\beta$ ) is rapidly induced after experimental brain injuries, and has emerged as a powerful driving force for leukocyte recruitment to the CNS (Gibson et al., 2004). IL- $1 \beta$ alone is capable of overriding the intrinsic resistance of the CNS to leukocyte infiltration, resulting in acute cellular recruitment to the brain parenchyma (Anthony et al., 1997; Proescholdt et al., 2002; Ferrari et al., 2004; Ching et al., 2005; Depino et al., 2005). Additionally, blocking the actions of IL- $1 \beta$ using the IL-1 receptor antagonist (IL-1ra) results in significant reductions in parenchymal leukocyte infiltration after injury (Garcia et al., 1995; Yang et al., 1998).

In experimental models of cerebral ischemia, infiltrating leu-

\footnotetext{
Received March 29, 2007; revised June 26, 2007; accepted July 7, 2007.

This work was supported by National Institutes of Health Grants NS33553 and NS048522. S.S.S. and T.J.C. are in the University of Rochester Medical Scientist Training Program (GM07356). We thank J. Miller for packaging of FIV, E. Hernady for preparation and cutting of paraffin-embedded tissue, J. Walter for assistance with animal colony management and sample preparation, I. King for help with flow cytometry, T. Montag for tissue staining, T. Murant and R. Johnson for assistance with ELISA, and L. Trojanczyk for aid with histological staining.

Correspondence should be addressed to Dr. M. Kerry O'Banion, University of Rochester Medical Center, 601

Elmwood Avenue, Box 603, Rochester, NY 14642. E-mail: kerry_obanion@urmc.rochester.edu.

DOI:10.1523/JNEUROSCI.1418-07.2007
}

Copyright $\odot 2007$ Society for Neuroscience $\quad 0270-6474 / 07 / 279301-09 \$ 15.00 / 0$ kocyte populations are thought to contribute to the resulting neuropathology. This hypothesis is based on the presence of leukocytes at sites of neuronal injury, their ability to elicit neurotoxicity ex vivo, and improvement in pathologic indices after attenuation of infiltrating leukocyte populations (Emerich et al., 2002). Accordingly, IL-1 $\beta$-mediated exacerbations of ischemic injury in rodents may involve potentiation of leukocyte recruitment to sites of injury (Rothwell, 2003). Among leukocytes, neutrophils have attracted much attention as the culprits in this phenomenon based on their ability to elicit tissue damage through the generation of toxic free radicals, release of proteolytic enzymes, and generation of proinflammatory cytokines (Kielian et al., 2001; Dinkel et al., 2004).

The chemokines of the ELR ${ }^{+}$CXC family are robust stimuli for the recruitment of neutrophils into both the CNS and peripheral tissues (Lee et al., 1995; Bell et al., 1996; Mehrad et al., 1999; Tateda et al., 2001; Lappalainen et al., 2005). The most potent and well defined members of this chemokine family in mice are keratinocyte-derived chemokine (KC) (or CXCL1) and macrophage inflammatory protein 2 (MIP-2) (or CXCL2), which signal exclusively through the CXCR2 receptor (Tessier et al., 1997; Mehrad et al., 1999; Del Rio et al., 2001; Kielian et al., 2001; Tateda et al., 2001). IL-1 $\beta$ is a powerful regulator of $\mathrm{KC}$ and MIP-2 expression within the CNS. Parenchymal IL- $1 \beta$ injection elicits induction of these chemokines and neutrophil recruitment to the rodent brain (Anthony et al., 1998).

To elucidate the role of chronic IL- $1 \beta$ activity in CNS leuko- 
cyte recruitment, we used the recently described IL- $1 \beta^{\mathrm{XAT}}$ transgenic mouse model to drive sustained hippocampal IL-1 $\beta$ expression (Shaftel et al., 2007). Surprisingly, IL- $1 \beta$ overexpression led to persistent leukocyte infiltration of the hippocampal parenchyma months after transgene activation. The resultant phenotype featured infiltration of diverse leukocyte populations and an absence of overt neurotoxicity. In addition, the downstream mechanisms of IL- $1 \beta$-driven neutrophil recruitment to the mouse brain were explored.

\section{Materials and Methods}

Transgenic mice. All animal procedures were reviewed and approved by the Institutional Animal Care and Use Committee (University of Rochester Committee on Animal Resources) for compliance with federal regulations before the initiation of the study. Creation and genotyping of the IL- $1 \beta^{\text {XAT }}$ mice on a C57BL/6 background has been described previously (Shaftel et al., 2007). Briefly, the IL- $1 \beta^{\text {XAT }}$ mice harbor a transgene construct consisting of a murine GFAP promoter (Stalder et al., 1998), loxP flanked transcriptional stop, and downstream ssIL- $1 \beta$ transgene coding for the signal sequence from the human IL-1 ra (75 bp) fused to the cDNA sequence of human mature IL-1 $\beta$ (464 bp) (Wingren et al., 1996). Transgene activation occurs after feline immunodeficiency virus (FIV)-Cre mediated excision of a transcriptional stop. Illr1 ${ }^{-1-}$ (stock no. 3245) and CXCR2 ${ }^{-1-}$ mice (stock no. 2724) were purchased from The Jackson Laboratory (Bar Harbor, ME). $\mathrm{CXCR}^{-1-}$ mice were backcrossed with IL- $1 \beta^{\mathrm{XAT}}$ mice resulting in a mixed BALB/c $\times$ C57BL/ 6 background. Genotyping was performed on DNA isolated from tail snips using the Wizard SV Genomic kit (Promega, Madison, WI) and screened by standard PCR using recommended primers (The Jackson Laboratory). Because of the presence of a neomycin resistance gene in both the targeting vector used for homologous recombinant knock-out of CXCR2 (Cacalano et al., 1994) and in the IL- $1 \beta^{\text {XAT }}$ construct (Shaftel et al., 2007), neomycin-specific primers were not useful for determining CXCR2 copy number. To accurately determine CXCR2 copy number, we discovered that the Nramp1 antimicrobial resistance gene lies within $\sim 250 \mathrm{~kb}$ of CXCR 2 on chromosome 1 and exhibits tight linkage (Cerretti et al., 1993). Strain differences exist between the 129/J source of the CXCR2 gene targeting vector and the $\mathrm{BALB} / \mathrm{c}$ source of the wild-type (WT) CXCR2 gene with respect to Nramp1 alleles. The Nramp $1{ }^{\text {res }}$ allele is only expressed by 129/J mice and therefore by mice lacking at least one copy of CXCR2 (Malo et al., 1994). Lack of the Nramp1 ${ }^{\text {res }}$ allele indicated that animals were in fact CXCR2 $^{+/+}$(Medina et al., 1996).

Feline immunodeficiency virus. The construction and packaging of FIV-Cre has been described previously (Lai et al., 2006). Briefly, The FIV-Cre virus encodes the nuclear localization sequence (nls), Cre recombinase protein (Cre), and V5 epitope tag under the control of a cytomegalovirus promoter. FIV-Cre, FIV-green fluorescent protein (GFP) (System Biosciences, Mountain View, CA) and FIV-LacZ (Invitrogen, Carlsbad, CA) were packaged to a final titer of $\sim 1 \times 10^{7}$ infectious viral particles (IVP) per ml. In vivo stereotactic injections were performed at $8-12$ weeks of age and used $1.5 \mu$ l of virus to deliver $\sim 1.5 \times$ $10^{4}$ IVP to the mouse hippocampus. Viral titering was performed in the $293^{\mathrm{FT}}$ cell line using an anti-V5 antibody, GFP fluorescence, or X-gal staining (Invitrogen).

Stereotactic injections. Intrahippocampal injections were described previously (Shaftel et al., 2007). Briefly, mice were anesthetized with $1.75 \%$ isoflurane in $30 / 70 \%$ oxygen/nitrogen gas. While secured to a
Kopf stereotaxic apparatus in a biosafety level 2 approved facility, a 0.5 $\mathrm{mm}$ burr hole was drilled in the skull at $-1.8 \mathrm{~mm}$ caudal and $1.8 \mathrm{~mm}$ horizontal from bregma. A preloaded 33 gauge needle was lowered 1.75 $\mathrm{mm}$ from the brain surface over $2 \mathrm{~min}$ after which $1.5 \mu \mathrm{l}$ of virus was injected at a constant rate over $10 \mathrm{~min}$. After allowing $5 \mathrm{~min}$ for diffusion of the virus, the needle was raised over $2 \mathrm{~min}$. The burr hole was sealed with bone wax and the scalp incision was closed with 6-0 nylon suture (Ethicon, Somerville, NJ).

Quantitative real-time PCR. General quantitative real-time PCR (qRTPCR) procedures have been described in detail previously (Shaftel et al., 2007). Briefly, hippocampal RNA was isolated using Trizol (Invitrogen). cDNA was generated using oligo-dT and random hexamer primers, and Superscript III (Invitrogen). Quantification of relative mRNA abundance was determined using custom designed primers (Invitrogen) and FAM 490 probes (Biosearch Technologies, Novato, CA) with the iCycler (Bio-Rad, Hercules, CA). PCRs were performed in a final volume of $25 \mu \mathrm{l}$ using iQ Supermix (Bio-Rad) and 5 nm FITC dye as follows: $95^{\circ} \mathrm{C}$ for 3 min, followed by 50 cycles of $95^{\circ} \mathrm{C}$ for $15 \mathrm{~s}$, and $60^{\circ} \mathrm{C}$ for $1 \mathrm{~min}$. Ribosomal 18 s housekeeping gene was used to normalize determinations of mRNA abundance. Sequences used were as follows: from $5^{\prime}$ to $3^{\prime}$, monocyte chemoattractant protein 1 (MCP-1) (CCL2), forward primer (F), ggctcagccagatgcagttaa, reverse primer $(\mathrm{R})$, cctactcattgggatcatcttgct, and probe $(\mathrm{P})$, ccccactcacctgctgctactcattca; intercellular adhesion molecule 1 (ICAM-1), F, ccccgcaggtccaattc, R, cagagcggcagagcaaaag, and P, cactgaatgccagctcggaggatcac; CXCR2, F, gtctttcagcatggctcattac, R, cgtgacctcttctccctgta, and P, agactgtggtatttgaattgatgcagcc; KC (CXCL1), F, gctaaaaggtgtccccaagtaa, R, taggaccctcaaaagaaattgta, and P, ctgctctgatggcaccgtctggt; MIP-2 (CXCL2), F, caagaacatccagagcttgagtgt, R, ttttgaccgcccttgagagt, and P, cccactgcgcccagacagaagtcat; 18s rRNA, F, cgaccataaacgatgccgact, R, gtggtgcccttccgtcaa, and P, cggcggcgttattcccatgacc.

Immunohistochemistry. Procedures were performed as described previously (Shaftel et al., 2007). Briefly, mice were intracardially flushed with $4 \%$ paraformaldehyde, and then the brain was postfixed for $2 \mathrm{~h}$ and dehydrated in $30 \%$ sucrose overnight (Sigma, St. Louis, MO). The samples were either snap frozen and sectioned at $30 \mu \mathrm{m}$ as described previously, or were embedded in paraffin for sectioning at $5 \mu \mathrm{m}$ thickness. Antibody binding was visualized using either Elite avidin-biotin and 3,3-diaminobenzidine (Vector Laboratories, Burlingame, CA) or secondary antibodies bound to Alexa 488 or 594 fluorophores (Invitrogen). Primary antibodies used were as follows: CD45 (Serotec, Raleigh, NC), 
A CD45
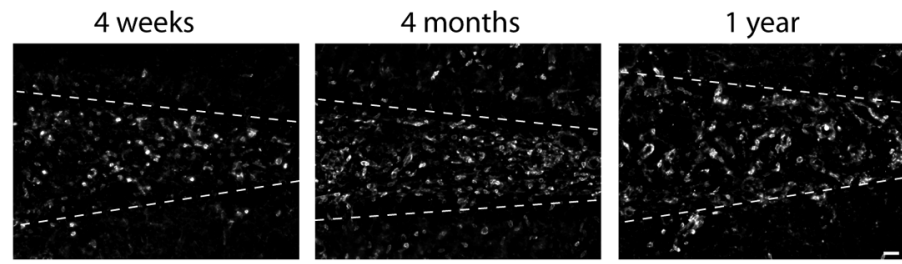

B

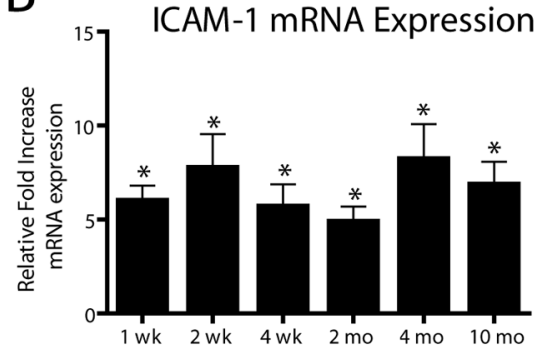

C

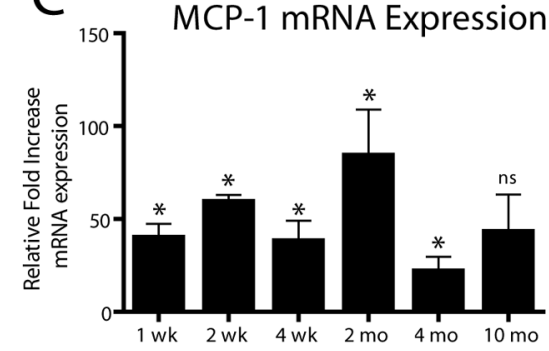

D
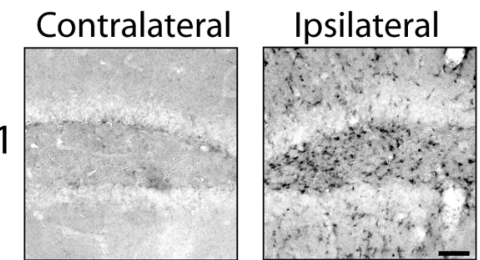

Figure 2. Induction of IL-1 $\beta$ expression drives chronic leukocyte recruitment to the mouse hippocampus. IL- $1 \beta^{\mathrm{XAT}}$ line $\mathrm{B} / \mathrm{b}$ mice received unilateral intrahippocampal injections of FIV-Cre and were analyzed over a prolonged time course. $A, C D 45$ staining in the ipsilateral (injected) hemispheres at the times indicated after FIV-Cre injection identifies infiltrating leukocytes. A white dashed line approximates the location of the granule cell layer of the dentate gyrus. qRT-PCR $(\boldsymbol{B}, \boldsymbol{C})$ generated a ratio of gene expression in the ipsilateral hippocampi of FIV-Cre injected IL-1 $\beta^{\mathrm{XAT}}$ mice compared with wild-type control animals at the same time point for ICAM-1 (B) and MCP-1 (CCL2) (C). D, Immunohistochemical detection of MCP-1 protein expression in the ipsilateral and contralateral hemispheres 2 weeks after FIV-Cre. $n=3-5$ animals per time point. Scale bars: $\boldsymbol{A}, 25 \mu \mathrm{m} ; \boldsymbol{D}, 50 \mu \mathrm{m}$. Graphs represent mean \pm SEM. ns, Not significant. ${ }^{*} p \leq 0.05$.

MCP-1 (R\&D Systems, Minneapolis, MN), CD3 (Santa Cruz Biotechnology, Santa Cruz, CA), CD4 (Serotec), CD8 (clone 53-6.72; American Type Culture Collection, Manassas, VA), CD11c (BD Pharmingen, San Diego, CA), 7/4 (Serotec), NeuN (Chemicon, Temecula, CA), KC (Abcam, Cambridge, MA), GFAP (Chemicon), and synaptophysin (clone YE269; Epitomics, Burlingame, CA). Hoechst 33258 (Invitrogen) and terminal deoxynucleotidyl transferase mediated dUTP nick end labeling (TUNEL) (ApopTag; Chemicon) were used according to manufacturer's protocols. For free floating sections, antibody concentrations were as follows: CD45 (1:100), MCP-1 (1:1000), 7/4 (1:5000), and synaptophy$\sin (1: 1000)$. For fluorescent staining, sections were mounted and stained directly on the slide with 1:20 dilutions of both primary and secondary antibodies. Acetylcholinesterase staining was performed as described previously (Hedreen et al., 1985) with the addition of $10 \mathrm{~mm}$ tetraisopropyl pyrophosphoramide to the incubation solution.

ELISA. Hippocampi from IL- $1 \beta^{\mathrm{XAT}}$ and WT mice $(n=6)$ were homogenized and vortexed in $20 \mu \mathrm{l}$ of T-PER (Pierce, Rockford, IL) per milligram of tissue weight with protease (EMD Biosciences, San Diego, CA) and phosphatase (Sigma) inhibitors followed by centrifugation for $1 \mathrm{~h}$ at $100,000 \times \mathrm{g}$. Determination of MCP- 1 and KC protein concentrations were made using the Beadlyte mouse 21-plex cytokine detection system (Upstate, Lake Placid, NY) according to the manufacturer's suggested protocols. Hippocampal supernatants and standards were diluted in T-PER. Results were read on the Luminex 100 System, and analyzed using Beadview software to calculate the mean and SEM (Upstate).

Blood-brain barrier permeability. Animals to be analyzed for bloodbrain barrier (BBB) leakage received bilateral hippocampal injections of FIV-Cre 2 weeks before analysis was to be performed. Mice received tail vein injections of $0.01 \mathrm{ml}$ per gram of body weight of $2 \%$ Evans Blue dye (Sigma) in buffered saline. After $2 \mathrm{~h}$, animals were intracardially flushed with $0.15 \mathrm{M}$ PBS, and the brain and liver were dissected and weighed. Samples were homogenized in $20 \mathrm{ml}$ of formamide per gram of tissue wet weight using an Omni 2000 tissue homogenizer (Omni International, Marietta, GA), followed by an overnight incubation at room temperature to allow for additional dye extraction. After centrifugation at $17,000 \times g$ for $30 \mathrm{~min}$, the OD of the supernatants was measured at 620 and $740 \mathrm{~nm}$. The following formula was used to calculate background absorbance: $-\log$ $\mathrm{OD}_{620}=(0.964)\left(-\log \mathrm{OD}_{740}\right)-0.0357($ Warnick et al., 1995). The corrected value for $\mathrm{OD}_{620}$ was generated by subtracting this background absorbance, and then by factoring in the absorbance in liver samples to control for differences in actual Evans Blue dye injected.

Flow cytometric analysis. The procedure followed was adapted from previously published methods (Campanella et al., 2002). After an intracardial flush with PBS, either the cortical hemisphere (see Fig. 3D) or hippocampi (see Fig. 7A) were quickly dissected into $2 \mathrm{ml}$ of HBSS (Invitrogen) to which $12 \mathrm{mg}$ of collagenase (Worthington Biochemical, Lakewood, NJ) and $20 \mathrm{mg}$ of DNase I (Sigma) were added in a $5 \mathrm{ml}$ final volume. Cells were gently dissociated in a $2 \mathrm{ml}$ glass homogenizer, and then forced through a $40 \mu \mathrm{m}$ nylon cell strainer. After incubation at $37^{\circ} \mathrm{C}$ for $45 \mathrm{~min}$, cells were carefully overlaid on a $30 / 70 \%$ room temperature Percoll (GE Healthcare, Piscataway, NJ) gradient and centrifuged at $1126 \times g$ for $20 \mathrm{~min}$ to enrich for leukocyte populations. Cells at the interphase were collected and pooled from within groups of animals. After centrifugation at $400 \times g$ for $10 \mathrm{~min}$, cells were resuspended in PBS containing 2\% FBS and counted. For surface antigen staining, cells were incubated with appropriate conjugated antibodies for $10 \mathrm{~min}$ on ice. Secondary staining with PerCP- or APC-conjugated streptavidin was performed for biotinylated primary antibodies. All stains were performed after blocking Fc receptors with FcBlock. Data acquisition used a FACSCalibur flow cytometer with CellQuest (BD Pharmingen) software. Ly6C-FITC (AL-21) and Ly6G-PE (1A8) were purchased from BD Pharmingen. CD45-FITC, CD11b-PE (M1/70), and M-CSF R-biotin (AFS98) were purchased from eBioscience (San Diego, CA). 2.4G2 (CD16/CD32 FcBlock) was grown at the University of Rochester School of Medicine and Dentistry and was purified on protein $\mathrm{G}$ columns.

Data analysis and image capture. Statistical significance was established using two-tailed Student's $t$ tests with significance set at $p<0.05$. Ipsilateral hemispheres from IL- $1 \beta$ overexpressing animals were compared with controls at the same time point whenever possible. For determination of granule cell density in Figure 5D, we used values from injected versus uninjected hemispheres within IL- $1 \beta$-overexpressing animals. Quantification of synaptophysin and acetylcholinesterase immunostaining in Figure 6 used the ratio of staining intensity between the ipsilateral and contralateral hemispheres within individual wild-type and IL- $1 \beta^{\mathrm{XAT}}$ animals to account for variability in staining intensity between individual sections. To quantify granule cells within the dentate gyrus, neurons were sampled within the upper (suprapyramidal) blade on two sets of $5 \mu \mathrm{m}$ paraffin sections stained with hematoxylin and eosin. Neurons were counted after sampling using 10 defined square sample regions within the ipsilateral and contralateral hippocampus. Granule cell densities were calculated using tissue thickness and sample areas. For synaptophysin and acetylcholinesterase quantification, mean gray values were measured in five separate equally sized areas within the upper blade of the molecular layer of the dentate gyrus using ImageJ software (http://rsb. info.nih.gov/ij/). Microsoft (Redmond, WA) Excel and Prism $5.0 \beta$ 
A

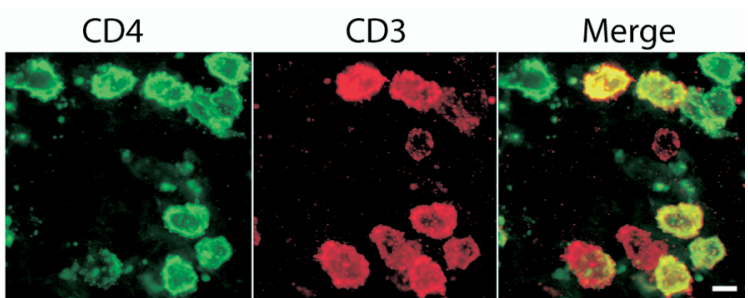

B

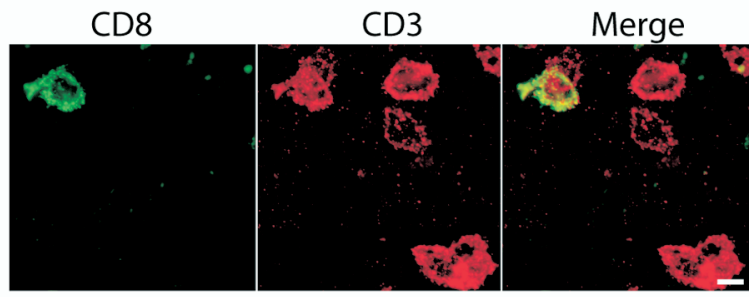

C

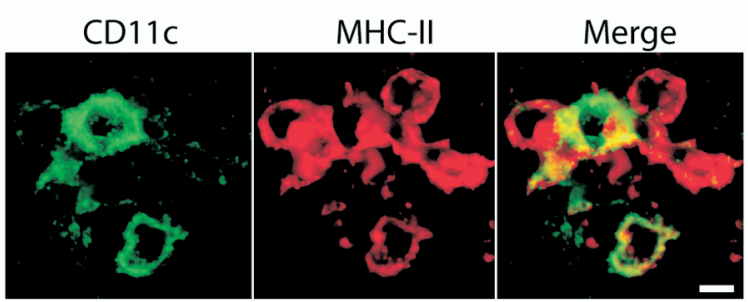

D

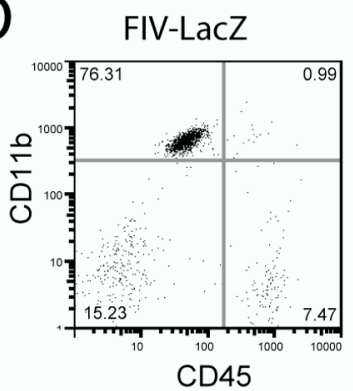

E

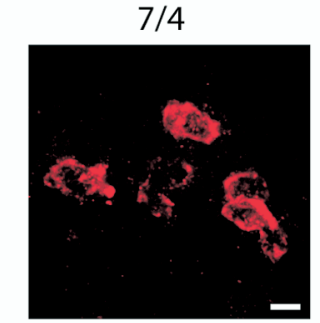

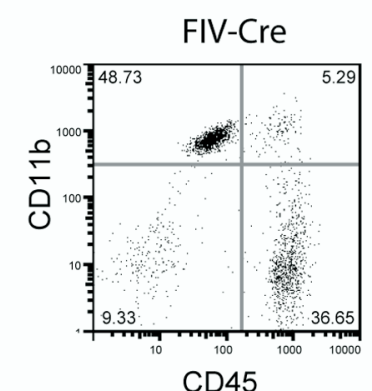

$\mathrm{F}$

$H \& E$

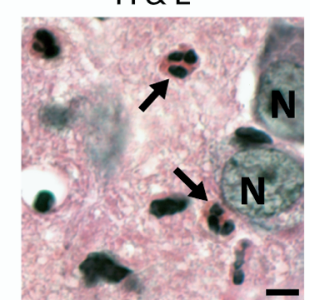

Figure 3. IL-1 $\beta$ expression recruits diverse leukocyte populations to the mouse hippocampus. Leukocyte populations were defined in the ipsilateral hippocampi of IL-1 $1 \beta^{\mathrm{XAT}}$ line $B / \mathrm{b}$ mice 2 weeks after gene activation by immunohistochemistry $(\boldsymbol{A}-\boldsymbol{C}, \boldsymbol{E})$, flow cytometry $(\boldsymbol{D})$, and tissue staining $(\boldsymbol{F}) . \boldsymbol{A}, \boldsymbol{B}, \mathrm{T}$-cell populations were identified and classified by their expression of CD3 (red) and either CD4 ( $\boldsymbol{A}$; green) or CD8 (B; green), where coexpressing cells appear yellow in merged images. $C$, The presence of dendritic cells was established by expression of both CD11C (green) and MHC-II (red), appearing yellow in merged images. $\boldsymbol{D}$, An increase in the number of infiltrating macrophages is demonstrated 2 weeks after FIV-Cre versus FIV-LacZ injection by expansion of the $\mathrm{CD} 45^{\mathrm{hi}}, \mathrm{CD} 11 \mathrm{~b}{ }^{+}$cell population. $\boldsymbol{E}, \boldsymbol{F}$, Neutrophils were identified by cellular labeling with the $7 / 4$ antibody $(\boldsymbol{E})$ and after hematoxylin and eosin (H\&E) tissue staining ( $\boldsymbol{F}$, arrows). N, Neuronal nuclei. Scale bars, $5 \mu \mathrm{m}$.

(GraphPad Software, San Diego, CA) were used for data analysis and graph generation. Light microscopic images were acquired on an Axioplan IIi (Zeiss, Thornwood, NY) microscope equipped with a Spot RT camera and software (Diagnostic Instruments, Sterling Heights, MI).
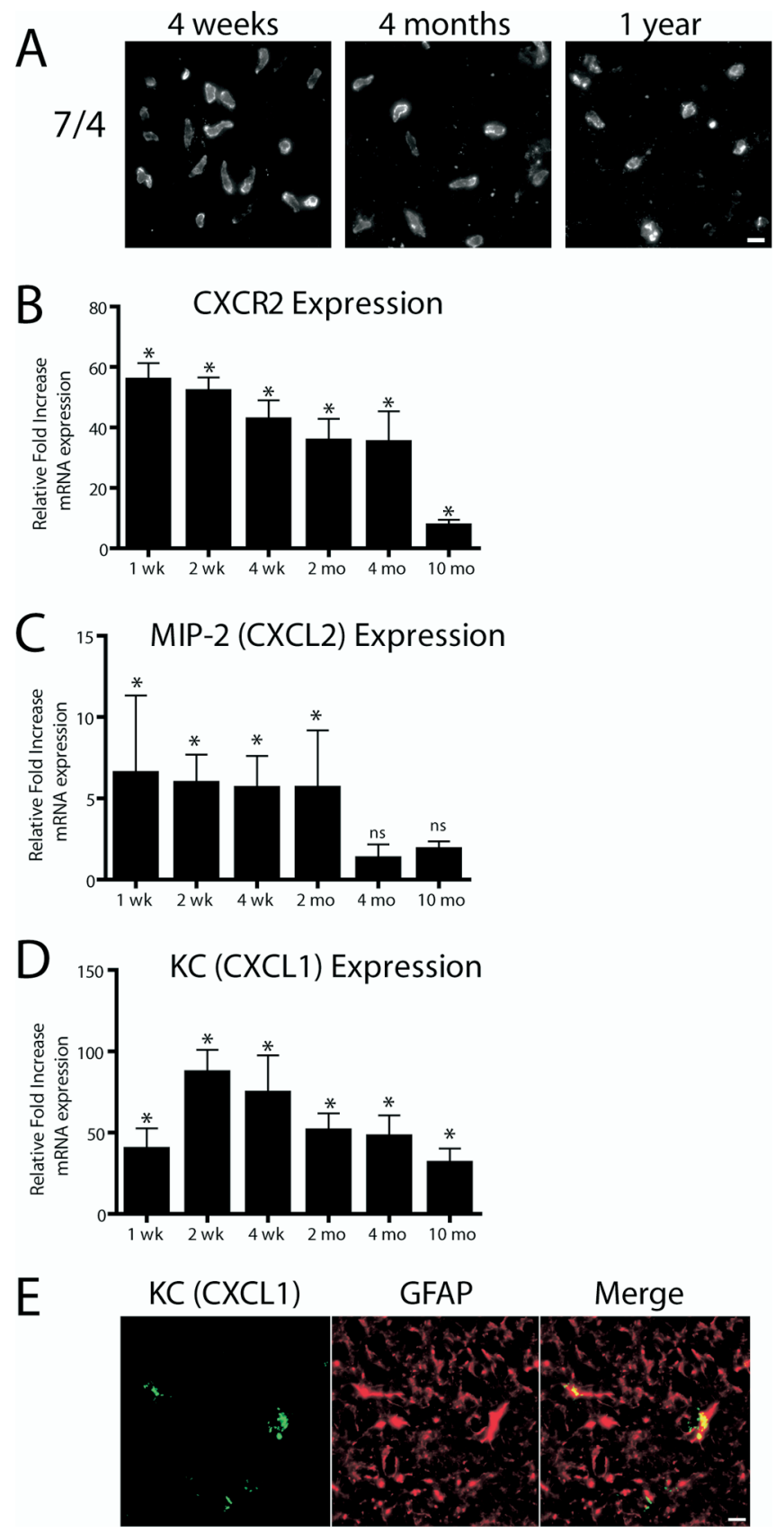

Figure 4. IL-1 $\beta$ transgene activation leads to sustained neutrophil recruitment to the hippocampus. $A$, Neutrophils were identified in the parenchyma of the dentate gyrus using the $7 / 4$ antibody at all time points assayed. Using qRT-PCR analysis $(\boldsymbol{B}-\boldsymbol{D})$, we determined relative gene expression in the ipsilateral hippocampi of FIV-Cre-injected IL- $1 \beta^{\text {XAT }}$ line B/b versus WT mice at the same time point. $B, C X C R 2$ expression was used as a surrogate marker for neutrophil infiltration and was significantly upregulated in the hippocampi of IL-1 $\beta^{\mathrm{XAT}}$ mice at all time points analyzed. C, MIP-2 (CXCL2) expression was significantly upregulated only until 2 months after transgene activation. $\boldsymbol{D}$, Significant, robust overexpression of the neutrophil chemotactic chemokine KC (CXCL1) was also detected at all time points. $\boldsymbol{E}$, Expression of KC (green) colocalizes with GFAP (red), appearing yellow in the ipsilateral hippocampus of an IL- $1 \beta^{\mathrm{XAT}}$ line $\mathrm{B} / \mathrm{b}$ mouse 4 weeks after FIV-Cre injection. $n=3-5$ animals per time point. Scale bars, $10 \mu \mathrm{m}$. Graphs represent mean \pm SEM. ns, Not significant. ${ }^{*} p \leq 0.05$.

Fluorescent images were captured using a AttoArc 2 (Zeiss) mercury lamp, Sensicam QE camera (Cooke, Romulus, MI), and Slidebook 4.0.2.2 software (Intelligent Imaging, Denver, CO) in Macintosh OS 10.4. Equivalent exposure times were used when comparing animal groups. Final images were generated in Photoshop CS2 and layout performed in Illustrator CS2 (Adobe, San Jose, CA). Flow cytometric plots 
A
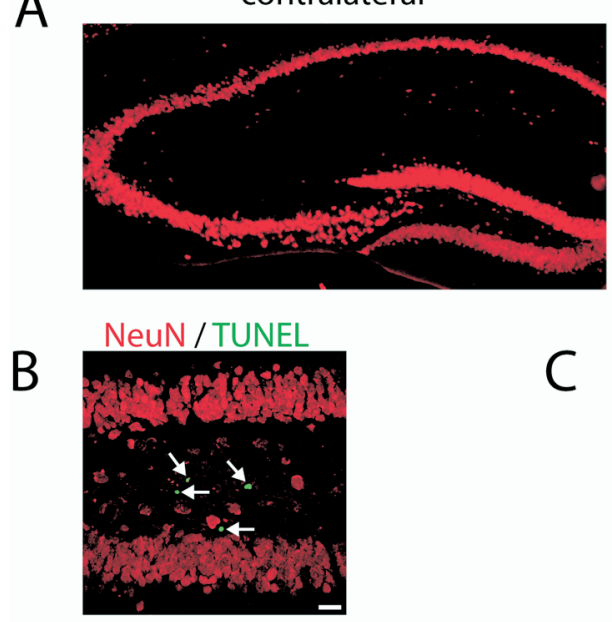
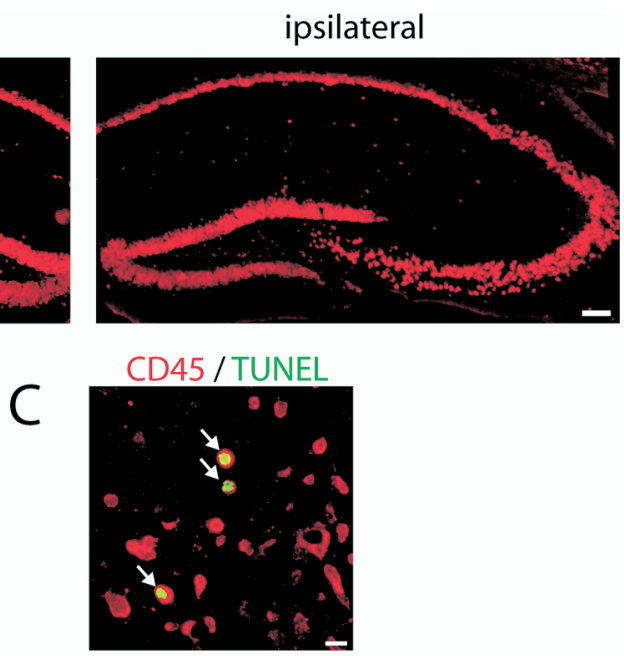

$\mathrm{D}$ Dentate Gyrus Neuronal Density

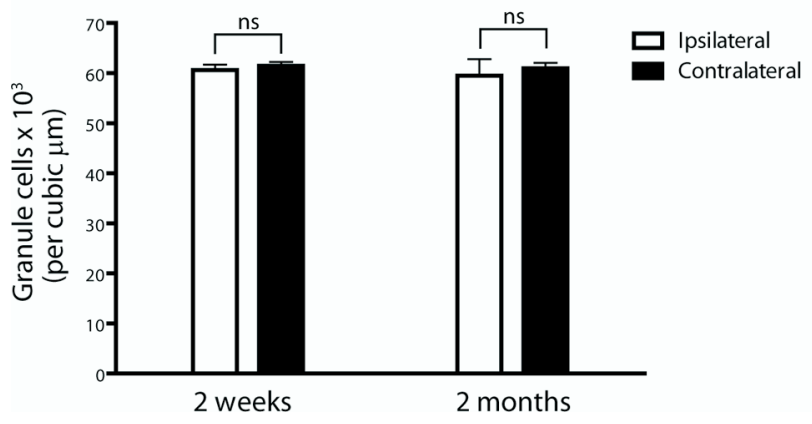

Figure 5. Neuronal toxicity is not evident after sustained hippocampal IL-1 $\beta$ expression. IL-1 $\beta^{\mathrm{XAT}}$ line $\mathrm{B} / \mathrm{b}$ mice received FIV-Cre injections and were analyzed 2 weeks or 2 months thereafter. Determination of neuronal toxicity was made comparing ipsilateral (injected) to noninjected (contralateral) hippocampi within animals. $\boldsymbol{A}$, Preservation of both the pyramidal and granule cell layers of the hippocampus is demonstrated using NeuN (red) in the ipsilateral and contralateral hippocampi 2 weeks after FIV-Cre injection. $\boldsymbol{B}$, NeuN (red) and TUNEL ${ }^{+}$cells (green, white arrows) 2 weeks after FIV-Cre injection. No overlap between these markers was detected. $\boldsymbol{C}$, Leukocytes undergoing apoptosis (yellow, indicated by white arrows) expressed both TUNEL (green) and CD45 (red) markers 2 weeks after FIV-Cre injection. D, Determination of granule cell density within the dentate gyrus of animals 2 weeks and 2 months after FIV-Cre injection. Statistical analysis compared the ipsilateral versus contralateral cellular density between groups of animals at the same time point. $n=3-4$ animals per time point. Scale bars: $\boldsymbol{A}, 100 \mu \mathrm{m} ; \boldsymbol{B}, 25 \mu \mathrm{m} ; \boldsymbol{C}, 10 \mu \mathrm{m}$. $n=3-4$ animals per time point. Graphs represent mean \pm SEM. ns, Not significant.

and data analysis were performed with FlowJo software (Tree Star, Ashland, OR).

\section{Results}

Hippocampal IL-1 $\beta$ expression leads to leukocyte infiltration and blood-brain barrier leakage

To create sustained overexpression of IL- $1 \beta$ within the CNS, we took advantage of the recently described IL- $1 \beta^{\mathrm{XAT}}$ transgenic model developed in our laboratory (Shaftel et al., 2007). IL$1 \beta^{\mathrm{XAT}}$ mice harbor a transgene cassette (Fig. $1 A$ ) featuring a GFAP promoter, loxP flanked transcriptional stop, and downstream transcriptionally silent human IL- $1 \beta$ transgene. Stereotactic injection of an FIV virus expressing Cre recombinase (FIVCre) into the mouse brain elicits transgene induction lasting months after viral transduction. We previously reported the elaboration of potent, long-lasting glial reactivity in response to transgene activation (Shaftel et al., 2007).

In the current study, we sought to examine the effects of sustained IL-1 $\beta$ expression on leukocyte recruitment to the brain parenchyma. We performed stereotactic injections of FIV-Cre or a control virus expressing GFP (FIV-GFP) into the dentate gyrus of adult WT or IL-1 $\beta^{\mathrm{XAT}}$ mice followed by initial analysis 2 weeks

after transgene induction (Fig. 1). We observed dramatic leukocyte infiltration of the hippocampal parenchyma of IL- $1 \beta^{\text {XAT }}$ mice using the pan-leukocyte marker CD45 (Fig. $1 B, C$ ). Cellular infiltration was spatially restricted to the FIV-Cre-injected (ipsilateral) hemisphere of IL- $1 \beta^{\mathrm{XAT}}$ mice (Fig. $1 B$ ). Leukocyte recruitment was more robust in IL- $1 \beta^{\mathrm{XAT}}$ line $\mathrm{B} / \mathrm{b}$ versus $\mathrm{A} / \mathrm{a}$ mice and completely absent in line $\mathrm{B} / \mathrm{b}$ animals lacking the sole receptor for IL$1 \beta$, IL-1R1 (Fig. 1C). Additionally, neither WT animals injected with FIV-Cre nor IL$1 \beta^{\mathrm{XAT}}$ animals receiving FIV-GFP injections demonstrated leukocyte infiltration (Fig. 1C). Based on demonstration of a more robust phenotype, $\mathrm{IL}-1 \beta^{\mathrm{XAT}}$ line $\mathrm{B} / \mathrm{b}$ animals were used in the remainder of the studies performed.

The infiltrative phenotype observed was accompanied by a significant increase in $\mathrm{BBB}$ leakage in the IL- $1 \beta^{\mathrm{XAT}}$ line $\mathrm{B} / \mathrm{b}$ mice. The albumin binding dye Evans Blue was used as a marker of serum protein extravasation across the BBB (Warnick et al., 1995). Two weeks after FIV-Cre injection, IL- $1 \beta^{\mathrm{XAT}}$ line $\mathrm{B} / \mathrm{b}$ mice demonstrated a 12.5-fold increase in hippocampal Evans Blue concentration relative to WT animals (Fig. 1D).

\section{IL-1 $\beta$ transgene activation drives} chronic leukocyte recruitment

To investigate the longevity of leukocyte infiltration in the IL- $1 \beta^{\mathrm{XAT}}$ mice, FIV-Cre injected animals were followed over a protracted time course after transgene activation (Fig. 2). CD $45^{+}$leukocytes were detected in the hippocampi of IL- $1 \beta^{\mathrm{XAT}}$ animals up to 1 year after FIV-Cremediated IL- $1 \beta$ transgene activation (Fig. $2 A)$. qRT-PCR was used to determine relative changes in copies of gene transcripts between IL- $1 \beta^{\mathrm{XAT}}$ and WT animals (Fig. $2 B, C$ ). The chronicity of cellular infiltration was mirrored by significant induction of ICAM-1 gene transcripts at all time points investigated (Fig. 2 B). Additionally, robust upregulation of MCP-1 (or CCL2) was detected at both the mRNA and protein level (Fig. 2C,D). Two weeks after transgene activation, MCP-1 was detected by ELISA in the ipsilateral hippocampi of IL- $1 \beta^{\mathrm{XAT}}$ animals $(1594.0 \pm 329.9 \mathrm{pg} / \mathrm{g})$ but not in WT mice (below detection limits).

\section{Diverse leukocyte populations are recruited by IL-1 $\beta$ expression}

We next characterized the infiltrating cell populations observed within the hippocampus of IL- $1 \beta^{\mathrm{XAT}}$ mice at 2 weeks after gene activation (Fig. 3). $\mathrm{CD}^{+}$T-cells were identified belonging to both $\mathrm{CD}^{+}{ }^{+}$and $\mathrm{CD} 8{ }^{+}$subpopulations, with $\mathrm{CD} 4{ }^{+}$T-cells accounting for the majority of cells identified (Fig. $3 A, B$ ). $\mathrm{CD}^{+}$ cells not labeled with CD3 (Fig. 3A) hinted at the presence of dendritic cells within the hippocampus, because they can demonstrate this staining pattern in mice (Shortman and Liu, 2002). The presence of dendritic cell populations was confirmed by cel- 
lular coexpression of CD11c and MHC-II (Fig. 3C). Using flow cytometry we were able to demonstrate a fivefold increase in the $\mathrm{CD} 45^{\mathrm{hi}} / \mathrm{CD} 11 \mathrm{~b}^{+}$cell population, indicative of increased numbers of macrophages present within the parenchyma of IL- $1 \beta^{\mathrm{XAT}}$ mice injected with FIV-Cre versus FIV-LacZ control virus (Fig. 3D) (Ford et al., 1995). Additionally, we identified neutrophils using the 7/4 anti-neutrophil antibody (Fig. 3E) (Hirsch and Gordon, 1983). This observation was further confirmed by demonstration of their distinct segmented nuclear morphology (Fig. $3 F$ ).

The time course of neutrophil infiltration was examined using the 7/4 antibody, and we were surprised to discover neutrophils in the dentate gyrus up to 1 year after induction of IL- $1 \beta$ overexpression (Fig. $4 A)$. CXCR2 is most highly expressed by neutrophils in mice, and was therefore used as a surrogate marker for the presence of neutrophils in the hippocampus (Mihara et al., 2005). Indeed, neutrophil infiltration mirrored significant induction of CXCR2 gene transcripts (Fig. 4B). Using qRT-PCR, we next focused on the expression of MIP-2 (CXCL2) and KC (CXCL1) gene transcripts within the hippocampus of IL- $1 \beta^{\mathrm{XAT}}$ mice. MIP-2 expression was significantly upregulated in the first 2 months after initiation of IL- $1 \beta$ overexpression (Fig. $4 C$ ). Expression of $\mathrm{KC}$ was markedly increased, with significant upregulation demonstrated at all time points assayed (Fig. 4D). Increases in KC mRNA expression correlated with significant upregulation of protein levels 2 weeks after transgene activation in ipsilateral hippocampi of IL- $1 \beta^{\text {XAT }}(2684.0 \pm 612.2 \mathrm{pg} / \mathrm{g})$ versus WT mice $(125.0 \pm 50.8 \mathrm{pg} / \mathrm{g})$ as detected by ELISA. KC protein expression was localized to astrocytes within the ipsilateral hippocampus of IL- $1 \beta^{\mathrm{XAT}}$ mice (Fig. $4 E$ ) but not to microglial populations (data not shown).

\section{Sustained IL-1 $\beta$ expression does not engender neurotoxicity} We were unable to detect evidence of overt neuronal toxicity in the dentate gyrus of IL- $1 \beta^{\mathrm{XAT}}$ mice after transgene activation (Figs. 5, 6). Using the neuronal marker NeuN, we observed maintenance of the hippocampal neuronal architecture (Fig. 5A). TUNEL, a cellular marker of apoptosis, was discovered in the dentate gyrus but was not localized to neurons (Fig. 5B). However, CD45 staining was found to overlap with TUNEL indicating the presence of leukocytes undergoing apoptosis (Fig. $5 C$ ). We also detected cells that colabeled with TUNEL and 7/4, representing apoptotic neutrophils (data not shown). In addition, we quantified granule cells within the dentate gyrus of IL- $1 \beta^{\text {XAT }}$ mice 2 weeks and 2 months after transgene activation and did not detect a significant decrease in neuronal density (Fig. 5D). Synaptophysin staining, which labels presynaptic vesicles, was not significantly altered in the molecular layer of the dentate gyrus of IL- $1 \beta^{\mathrm{XAT}}$ mice versus wild-type animals at these same time points (Fig. $6 A, B$ ). Acetylcholinesterase histochemistry, which labels cholinergic nerve fibers, was also not significantly changed at 2 weeks or 2 months after transgene activation (Fig. 6C,D).
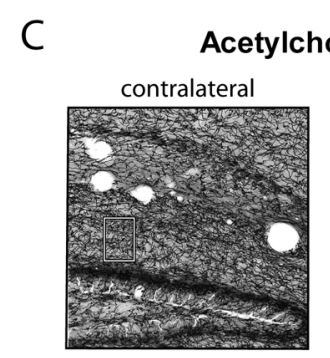

Synaptophysin

B

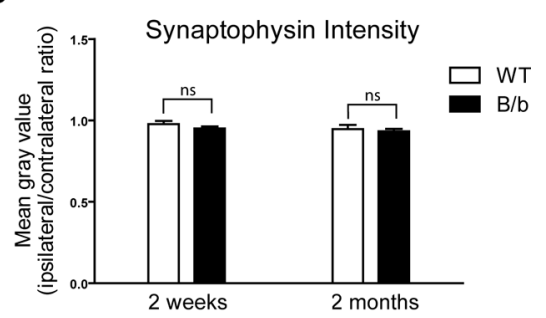

D
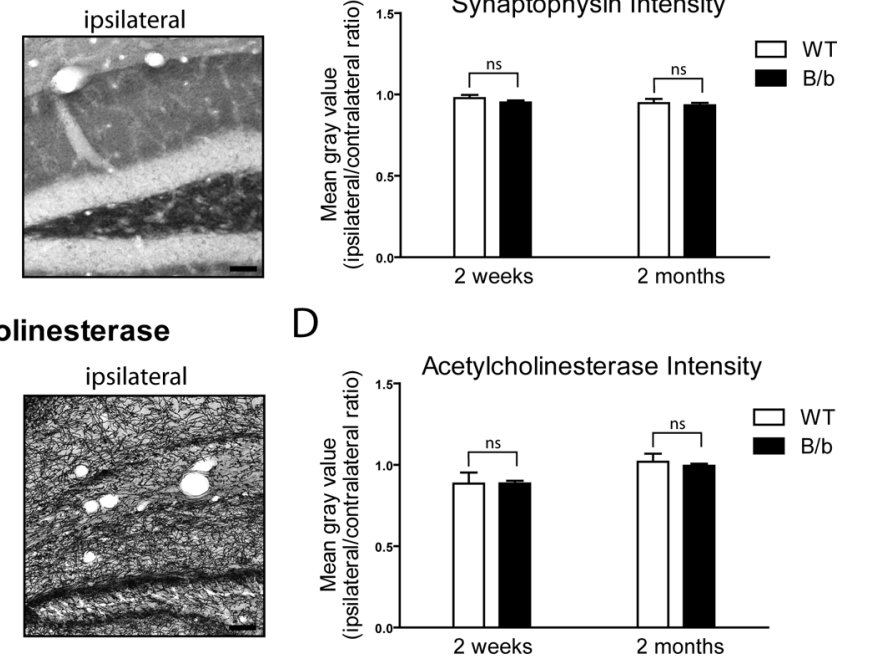
NT .

Figure 6. IL-1 $\beta$ transgene activation does not cause changes in neuronal integrity. $A$, Synaptophysin staining in the contralatfication $(\boldsymbol{D})$ as described in $\boldsymbol{A}$ and $\boldsymbol{B}$ above. $n=3-5$ animals per time point, $1-3$ sections per animal analyzed. Scale bars, $50 \mu \mathrm{m}$.

\section{Blood-brain barrier leakage does not require neutrophil infiltration}

To elucidate the mechanism of IL- $1 \beta$-mediated recruitment of neutrophils to the hippocampus, we crossed the IL- $1 \beta^{\mathrm{XAT}}$ animals with mice lacking CXCR2, the only receptor for $\mathrm{KC}$ and MIP-2 (Fig. 7). IL-1 $\beta^{\mathrm{XAT}}$ mice homozygous (CXCR2 ${ }^{+/+}$), heterozygous $\left(\mathrm{CXCR} 2^{+/-}\right.$), or completely lacking CXCR2 $\left(\mathrm{CXCR} 2^{-1-}\right)$ were produced, and evaluated for their capacity to recruit neutrophils 2 weeks after transgene activation. Flow cytometric analysis demonstrated a robust effect of CXCR2 gene dosage on IL-1 $\beta$-mediated neutrophil infiltration (Fig. $7 A$ ). Compared with CXCR2 ${ }^{+/+}$animals, CXCR2 ${ }^{+/-}$mice had a $45 \%$ reduction ( 4.55 vs $2.51 \%$ gated cells) in neutrophils, whereas CXCR2 knock-outs showed a 96\% reduction (4.55 vs $0.18 \%$ ). Immunohistochemical detection of neutrophils using the 7/4 antibody confirmed these observations (Fig. 7B). The lack of infiltrating neutrophils did not result in significant changes in the degree of protein extravasation into the hippocampus. Using Evans Blue dye as an indicator of BBB leakage, we discovered BBB leakage in all groups of animals. Moreover, there were no significant differences between $\mathrm{CXCR} 2^{+/+}, \mathrm{CXCR} 2^{+/-}$, and $\mathrm{CXCR}^{-\prime-}$ animals 2 weeks after activation of the IL- $1 \beta$ transgene (Fig. 7C).

\section{Discussion}

This study is the first to explore the effect of sustained IL- $1 \beta$ overexpression within the mouse brain on leukocyte recruitment and was made possible by the recent development of the IL$1 \beta^{\mathrm{XAT}}$ mouse (Shaftel et al., 2007). This transgenic model allows for control of the transcriptional initiation of an IL- $1 \beta$ transgene (Fig. $1 A$ ) and provides for long-term overexpression of IL- $1 \beta$ within the mouse brain. We found that sustained hippocampal IL- $1 \beta$ overexpression was able to drive localized, persistent leukocyte infiltration of the brain parenchyma as much as 1 year after transgene activation (Fig. $2 A$ ).

The ability of IL- $1 \beta$ to continually recruit leukocytes to the 

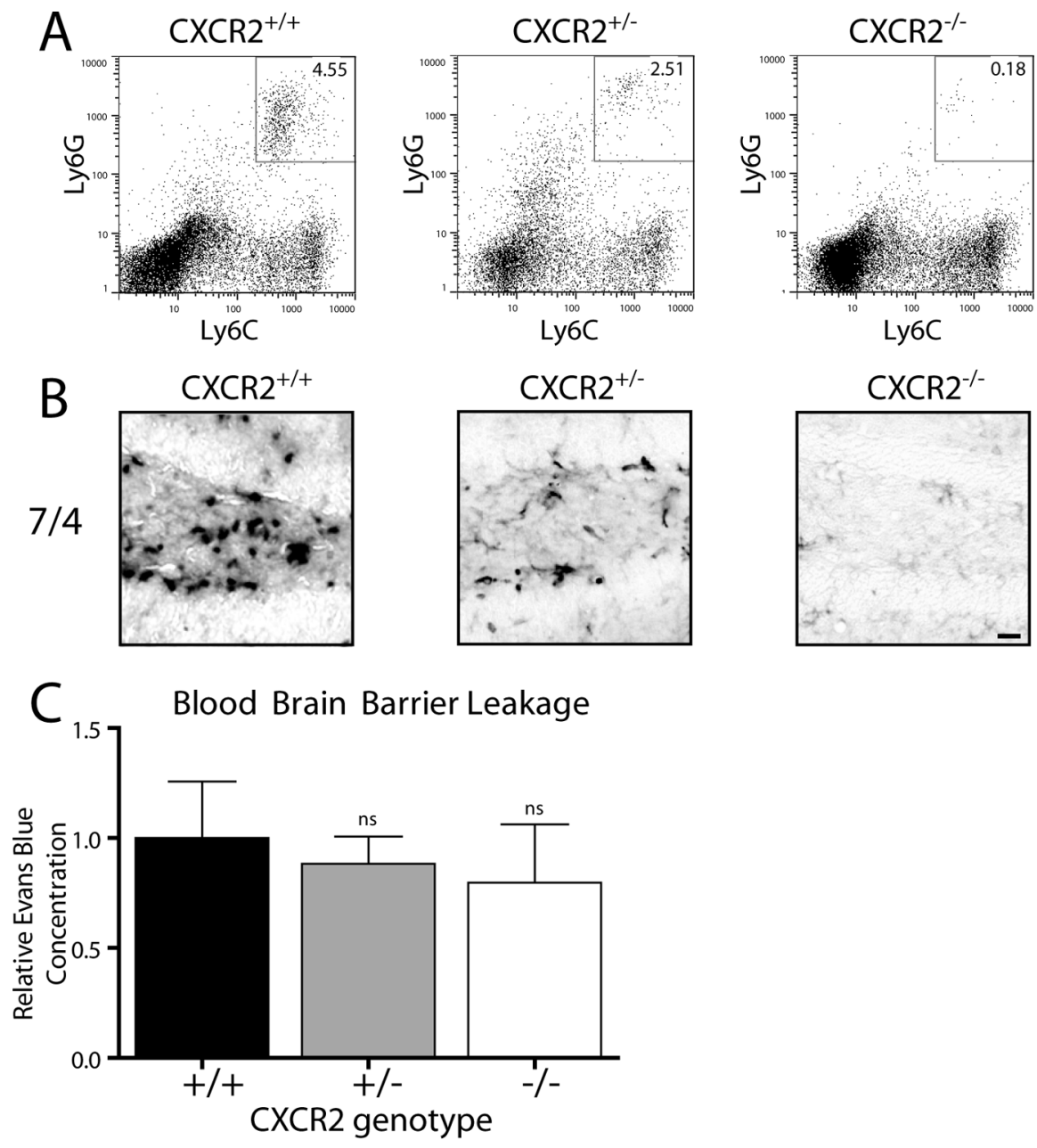

Figure 7. $\quad$ CXCR2 is required for neutrophil infiltration after hippocampal IL-1 $\beta$ expression. IL-1 $\beta^{\mathrm{XAT}}$ line $\mathrm{B} / \mathrm{b}$ animals either lacking $\left(C X C R 2^{-/-}\right)$, heterozygous (CXCR2 $\left.{ }^{+/}\right)$, or with two copies (CXCR2 ${ }^{+/+}$) of CXCR2 were examined 2 weeks after FIV-Cre hippocampal injections. A, Hippocampal cellular infiltrates from bilaterally injected mice were analyzed by flow cytometry. After gating on M-CSF-negative cells, the percentage of neutrophils are indicated in the top right corner of each plot as the Lys $6 \mathrm{G}^{\text {hi }}$, Lys $6{ }^{\mathrm{hi}}$ cell population. $\boldsymbol{B}, 7 / 4$ staining of neutrophils within the dentate gyrus reflects the results from $\boldsymbol{A}$. C, BBB leakage was determined using hippocampal Evans Blue concentrations and is graphed relative to that observed in $\mathrm{CXCR2} 2^{+1+}$ animals. BBB leakage was present in all animal groups and was not significantly altered by CXCR2 gene dosage. $n=3-4$ animals per group. Scale bar, $20 \mu \mathrm{m}$. Graphs represent mean \pm SEM. ns, Not significant.

mouse brain is likely facilitated by prolonged induction of ICAM-1 and MCP-1 (CCL2) expression (Fig. 2B-D). Cell adhesion molecules, such as ICAM-1, are expressed primarily on the vasculature and are essential in binding leukocyte-expressed integrins (Callahan and Ransohoff, 2004). Increased expression of ICAM-1 could potentiate leukocyte arrest along the vasculature and eventual migration into the parenchyma. MCP-1 is primarily credited with recruitment of macrophage populations to sites of expression but is also capable of acting as a T-cell and dendritic cell chemotactic stimulus (Carr et al., 1994; Fuentes et al., 1995; Caux et al., 2000; Bennett et al., 2003). Sustained increases in ICAM-1 and MCP-1 (Fig. $2 B-D$ ) could act synergistically to recruit diverse leukocyte populations to the mouse brain (Fig. $3 A-$ $D)$. Future studies will help determine other factors contributing to prolonged leukocyte recruitment in the IL- $1 \beta^{\mathrm{XAT}}$ mouse model.

The capacity of sustained IL- $1 \beta$ expression to drive robust MCP-1 induction is important because it may contribute to the pathogenesis of chronic neuroinflammatory diseases. For example, in multiple sclerosis (MS), IL-1 $\beta$ expression is localized to active lesions and CSF levels are reported to correlate with disease severity (Hauser et al., 1990; McGuinness et al., 1997). Theoretically, this parenchymal IL- $1 \beta$ expression may trigger MCP-1 induction and potentiate recruitment of encephalitogenic leukocytes to active lesions. Indeed, data from animal models provide evidence that MCP-1 may be intimately involved in MS disease pathogenesis. In experimental autoimmune encephalomyelitis models of disease, absence of MCP-1 or its receptor CCR2 have been observed to confer disease resistance or significant attenuation of the resulting phenotype (Izikson et al., 2000; Huang et al., 2001).

Additional inspection of the phenotype resulting from sustained hippocampal IL- $1 \beta$ expression revealed significant contribution of neutrophils to the population of infiltrating leukocytes (Figs. $3 F, 4 A$ ). Neutrophils are an important feature of the mammalian acute phase response and are quickly cleared within days after injury (Nathan, 2006). Neutrophil infiltration has not been reported beyond 3 weeks after targeting of IL- $1 \beta$ to the rodent brain, either after single bolus injection or expression by an adenoviral vector (Anthony et al., 1997, 1998; Ferrari et al., 2004). Our results suggest that persistent infiltration of neutrophils is taking place in the IL$1 \beta^{\mathrm{XAT}}$ mice, because neutrophils are incapable of surviving more than a few days after leaving the circulation (Simon, 2003). Consequently, demonstration of neutrophils in the hippocampal parenchyma of IL- $1 \beta^{\mathrm{XAT}}$ mice as much as 1 year after transgene activation (Fig. $4 A$ ) represents a novel finding and provides evidence that sustained IL- $1 \beta$ expression is both a potent and enduring stimulus for neutrophil recruitment.

Despite the continued expression of IL- $1 \beta$ and infiltration of leukocytes, there was no evidence of neuronal death in the hippocampus of IL- $1 \beta^{\mathrm{XAT}}$ mice (Fig. $5 A, B, D$ ). This observation is in general agreement with the literature in vivo, which suggests that IL- $1 \beta$ expression is not capable of neurotoxicity by itself but may serve to lower the threshold for additional injury (Rothwell, 2003; Ferrari et al., 2004; Hailer et al., 2005). Indeed, when expressed in concert with CNS injuries such as ischemia or excitotoxicity, IL-1 $\beta$ can produce marked exacerbations of neuronal injury in the affected regions (Allan et al., 2005; Patel et al., 2006). To our knowledge, there exists only one report of IL- $1 \beta$-mediated hippocampal neurodegeneration in which a single bolus injection was delivered to the rat brain (Depino et al., 2005). However, neuronal death was apparent only directly adjacent to the needle tract, and may have resulted from synergy of IL-1 activity with the demonstrated tissue injury caused by the injection.

We also investigated more subtle changes in the dentate gyrus that may have resulted from sustained IL- $1 \beta$ overexpression using synaptophysin and acetylcholinesterase, markers of presynaptic vesicles and cholinergic neuronal processes, respectively 
(Fig. 6). We did not detect significant differences in staining intensity for these markers in IL- $1 \beta^{\mathrm{XAT}}$ transgenic versus wild-type animals at the time points analyzed. This provides additional evidence that sustained IL- $1 \beta$ overexpression in the mouse hippocampus does not cause overt changes in neuronal integrity. However, our study was limited to neurons in the dentate gyrus, and it is possible that sustained IL- $1 \beta$ expression may elicit neurotoxicity in other brain regions.

Our results indicate that the ELR ${ }^{+}$CXC chemokines are essential to IL- $1 \beta$-driven neutrophil recruitment to the CNS parenchyma. Among the $\mathrm{ELR}^{+} \mathrm{CXC}$ chemokines, $\mathrm{KC}$ (CXCL1) is likely the most potent neutrophil chemotactic stimulus downstream of IL- $1 \beta$. In rodents, constitutive expression of $\mathrm{KC}$ is sufficient to drive continual neutrophil recruitment to the mouse brain, whereas antibody blockade results in dramatic reductions in infiltrating neutrophils (Tani et al., 1996; Anthony et al., 1998). In the IL- $1 \beta^{\mathrm{XAT}}$ mice, $\mathrm{KC}$ is both robustly and chronically overexpressed compared with MIP-2 (CXCL2), which is significantly upregulated only until 2 months after transgene activation (Fig. $4 C, D)$.

We demonstrated that expression of the CXCR2 receptor is required for efficient neutrophil recruitment to the brain parenchyma (Fig. $7 A, B$ ). This is an important observation, because blockade of the CXCR2 receptor may be an efficient means of limiting neutrophil infiltration into sites of CNS inflammation and represents a potential therapeutic target (Busch-Petersen, 2006). In rats, it has been suggested that neutrophils are required for IL-1 $\beta$-mediated increases in BBB permeability (Anthony et al., 1997, 1998). However, our data suggest that other mechanisms associated with the persistent neuroinflammatory response in these animals are responsible for IL- $1 \beta$-mediated BBB leakage in mice (Fig. 7C). Despite the virtual absence of neutrophil infiltration in IL- $1 \beta^{\mathrm{XAT}}$ line $\mathrm{B} / \mathrm{b}$ mice lacking the CXCR2 receptor (Fig. $7 A, B$ ), we did not observe significant differences in BBB permeability between these animals and those expressing CXCR2 (Fig. 7C).

In conclusion, this study has provided valuable insight into inflammatory mechanisms of leukocyte recruitment to the CNS using a novel model of sustained IL- $1 \beta$ overexpression in the mouse brain. We demonstrated that IL- $1 \beta$ is capable of driving persistent cellular infiltration of the brain parenchyma without engendering explicit neuropathology. In addition, we provided a mechanistic basis for IL- $1 \beta$-directed neutrophil infiltration. This study emphasizes the centrality of IL- $1 \beta$ signaling to CNS leukocyte recruitment and provides a valuable model for additional mechanistic exploration of the role of sustained IL- $1 \beta$ expression in the pathogenesis of CNS diseases.

\section{References}

Allan SM, Tyrrell PJ, Rothwell NJ (2005) Interleukin-1 and neuronal injury. Nat Rev Immunol 5:629-640.

Anthony D, Dempster R, Fearn S, Clements J, Wells G, Perry VH, Walker K (1998) CXC chemokines generate age-related increases in neutrophilmediated brain inflammation and blood-brain barrier breakdown. Curr Biol 8:923-926.

Anthony DC, Bolton SJ, Fearn S, Perry VH (1997) Age-related effects of interleukin-1 beta on polymorphonuclear neutrophil-dependent increases in blood-brain barrier permeability in rats. Brain 120:435-444.

Bell MD, Taub DD, Perry VH (1996) Overriding the brain's intrinsic resistance to leukocyte recruitment with intraparenchymal injections of recombinant chemokines. Neuroscience 74:283-292.

Bennett JL, Elhofy A, Canto MC, Tani M, Ransohoff RM, Karpus WJ (2003) CCL2 transgene expression in the central nervous system directs diffuse infiltration of CD $455^{\text {high }} \mathrm{CD} 11 \mathrm{~b}^{+}$monocytes and enhanced Theiler's mu- rine encephalomyelitis virus-induced demyelinating disease. J Neurovirol 9:623-636.

Busch-Petersen J (2006) Small molecule antagonists of the CXCR2 and CXCR1 chemokine receptors as therapeutic agents for the treatment of inflammatory diseases. Curr Top Med Chem 6:1345-1352.

Cacalano G, Lee J, Kikly K, Ryan AM, Pitts-Meek S, Hultgren B, Wood WI, Moore MW (1994) Neutrophil and B cell expansion in mice that lack the murine IL-8 receptor homolog. Science 265:682-684.

Callahan MK, Ransohoff RM (2004) Analysis of leukocyte extravasation across the blood-brain barrier: conceptual and technical aspects. Curr Allergy Asthma Rep 4:65-73.

Campanella M, Sciorati C, Tarozzo G, Beltramo M (2002) Flow cytometric analysis of inflammatory cells in ischemic rat brain. Stroke 33:586-592.

Carr MW, Roth SJ, Luther E, Rose SS, Springer TA (1994) Monocyte chemoattractant protein 1 acts as a T-lymphocyte chemoattractant. Proc Natl Acad Sci USA 91:3652-3656.

Caux C, Ait-Yahia S, Chemin K, de Bouteiller O, Dieu-Nosjean MC, Homey B, Massacrier C, Vanbervliet B, Zlotnik A, Vicari A (2000) Dendritic cell biology and regulation of dendritic cell trafficking by chemokines. Springer Semin Immunopathol 22:345-369.

Cerretti DP, Nelson N, Kozlosky CJ, Morrissey PJ, Copeland NG, Gilbert DJ, Jenkins NA, Dosik JK, Mock BA (1993) The murine homologue of the human interleukin-8 receptor type B maps near the Ity-Lsh-Bcg disease resistance locus. Genomics 18:410-413.

Ching S, He L, Lai W, Quan N (2005) IL-1 type I receptor plays a key role in mediating the recruitment of leukocytes into the central nervous system. Brain Behav Immun 19:127-137.

Del Rio L, Bennouna S, Salinas J, Denkers EY (2001) CXCR2 deficiency confers impaired neutrophil recruitment and increased susceptibility during Toxoplasma gondii infection. J Immunol 167:6503-6509.

Depino A, Ferrari C, Pott Godoy MC, Tarelli R, Pitossi FJ (2005) Differential effects of interleukin-1beta on neurotoxicity, cytokine induction and glial reaction in specific brain regions. J Neuroimmunol 168:96-110.

Dinkel K, Dhabhar FS, Sapolsky RM (2004) Neurotoxic effects of polymorphonuclear granulocytes on hippocampal primary cultures. Proc Natl Acad Sci USA 101:331-336.

Emerich DF, Dean III RL, Bartus RT (2002) The role of leukocytes following cerebral ischemia: pathogenic variable or bystander reaction to emerging infarct? Exp Neurol 173:168-181.

Ferrari CC, Depino AM, Prada F, Muraro N, Campbell S, Podhajcer O, Perry VH, Anthony DC, Pitossi FJ (2004) Reversible demyelination, bloodbrain barrier breakdown, and pronounced neutrophil recruitment induced by chronic IL-1 expression in the brain. Am J Pathol 165:1827-1837.

Ford AL, Goodsall AL, Hickey WF, Sedgwick JD (1995) Normal adult ramified microglia separated from other central nervous system macrophages by flow cytometric sorting. Phenotypic differences defined and direct ex vivo antigen presentation to myelin basic protein-reactive $\mathrm{CD} 4{ }^{+} \mathrm{T}$ cells compared. J Immunol 154:4309-4321.

Fuentes ME, Durham SK, Swerdel MR, Lewin AC, Barton DS, Megill JR, Bravo R, Lira SA (1995) Controlled recruitment of monocytes and macrophages to specific organs through transgenic expression of monocyte chemoattractant protein-1. J Immunol 155:5769-5776.

Garcia JH, Liu KF, Relton JK (1995) Interleukin-1 receptor antagonist decreases the number of necrotic neurons in rats with middle cerebral artery occlusion. Am J Pathol 147:1477-1486.

Gibson RM, Rothwell NJ, Le Feuvre RA (2004) CNS injury: the role of the cytokine IL-1. Vet J 168:230-237.

Hailer NP, Vogt C, Korf HW, Dehghani F (2005) Interleukin-1 beta exacerbates and interleukin-1 receptor antagonist attenuates neuronal injury and microglial activation after excitotoxic damage in organotypic hippocampal slice cultures. Eur J Neurosci 21:2347-2360.

Hauser SL, Doolittle TH, Lincoln R, Brown RH, Dinarello CA (1990) Cytokine accumulations in CSF of multiple sclerosis patients: frequent detection of interleukin-1 and tumor necrosis factor but not interleukin-6. Neurology 40:1735-1739.

Hedreen JC, Bacon SJ, Price DL (1985) A modified histochemical technique to visualize acetylcholinesterase-containing axons. J Histochem Cytochem 33:134-140.

Hirsch S, Gordon S (1983) Polymorphic expression of a neutrophil differentiation antigen revealed by monoclonal antibody $7 / 4$. Immunogenetics $18: 229-239$. 
Huang DR, Wang J, Kivisakk P, Rollins BJ, Ransohoff RM (2001) Absence of monocyte chemoattractant protein 1 in mice leads to decreased local macrophage recruitment and antigen-specific $\mathrm{T}$ helper cell type $1 \mathrm{im}$ mune response in experimental autoimmune encephalomyelitis. J Exp Med 193:713-726.

Izikson L, Klein RS, Charo IF, Weiner HL, Luster AD (2000) Resistance to experimental autoimmune encephalomyelitis in mice lacking the CC chemokine receptor (CCR)2. J Exp Med 192:1075-1080.

Kielian T, Barry B, Hickey WF (2001) CXC chemokine receptor-2 ligands are required for neutrophil-mediated host defense in experimental brain abscesses. J Immunol 166:4634-4643.

Lai YC, Shaftel SS, Miller JN, Tallents RH, Chang Y, Pinkert CA, Olschowka JA, Dickerson IM, Puzas JE, O’Banion MK, Kyrkanides S (2006) Intraarticular induction of interleukin-1beta expression in the adult mouse, with resultant temporomandibular joint pathologic changes, dysfunction, and pain. Arthritis Rheum 54:1184-1197.

Lappalainen U, Whitsett JA, Wert SE, Tichelaar JW, Bry K (2005) Interleukin-1beta causes pulmonary inflammation, emphysema, and airway remodeling in the adult murine lung. Am J Respir Cell Mol Biol 32:311-318.

Lee J, Cacalano G, Camerato T, Toy K, Moore MW, Wood WI (1995) Chemokine binding and activities mediated by the mouse IL-8 receptor. J Immunol 155:2158-2164.

Malo D, Vogan K, Vidal S, Hu J, Cellier M, Schurr E, Fuks A, Bumstead N, Morgan K, Gros P (1994) Haplotype mapping and sequence analysis of the mouse Nramp gene predict susceptibility to infection with intracellular parasites. Genomics 23:51-61.

McGuinness MC, Powers JM, Bias WB, Schmeckpeper BJ, Segal AH, Gowda VC, Wesselingh SL, Berger J, Griffin DE, Smith KD (1997) Human leukocyte antigens and cytokine expression in cerebral inflammatory demyelinative lesions of X-linked adrenoleukodystrophy and multiple sclerosis. J Neuroimmunol 75:174-182.

Medina E, Rogerson BJ, North RJ (1996) The Nramp 1 antimicrobial resistance gene segregates independently of resistance to virulent Mycobacterium tuberculosis. Immunology 88:479-481.

Mehrad B, Strieter RM, Moore TA, Tsai WC, Lira SA, Standiford TJ (1999) CXC chemokine receptor-2 ligands are necessary components of neutrophil-mediated host defense in invasive pulmonary aspergillosis. J Immunol 163:6086-6094.

Mihara K, Smit MJ, Krajnc-Franken M, Gossen J, Rooseboom M, Dokter W (2005) Human CXCR2 (hCXCR2) takes over functionalities of its murine homolog in hCXCR2 knockin mice. Eur J Immunol 35:2573-2582.

Morganti-Kossmann MC, Rancan M, Stahel PF, Kossmann T (2002) Inflammatory response in acute traumatic brain injury: a double-edged sword. Curr Opin Crit Care 8:101-105.

Nathan C (2006) Neutrophils and immunity: challenges and opportunities. Nat Rev Immunol 6:173-182.

Patel HC, Ross FM, Heenan LE, Davies RE, Rothwell NJ, Allan SM (2006) Neurodegenerative actions of interleukin-1 in the rat brain are mediated through increases in seizure activity. J Neurosci Res 83:385-391.
Proescholdt MG, Chakravarty S, Foster JA, Foti SB, Briley EM, Herkenham M (2002) Intracerebroventricular but not intravenous interleukin-1beta induces widespread vascular-mediated leukocyte infiltration and immune signal mRNA expression followed by brain-wide glial activation. Neuroscience 112:731-749.

Ransohoff RM, Kivisakk P, Kidd G (2003) Three or more routes for leukocyte migration into the central nervous system. Nat Rev Immunol 3:569-581.

Rothwell N (2003) Interleukin-1 and neuronal injury: mechanisms, modification, and therapeutic potential. Brain Behav Immun 17:152-157.

Shaftel SS, Kyrkanides S, Olschowka JA, Miller JN, Johnson RE, O'Banion MK (2007) Sustained hippocampal IL-1beta overexpression mediates chronic neuroinflammation and ameliorates Alzheimer plaque pathology. J Clin Invest 117:1595-1604.

Shortman K, Liu YJ (2002) Mouse and human dendritic cell subtypes. Nat Rev Immunol 2:151-161.

Simon HU (2003) Neutrophil apoptosis pathways and their modifications in inflammation. Immunol Rev 193:101-110.

Stalder AK, Carson MJ, Pagenstecher A, Asensio VC, Kincaid C, Benedict M, Powell HC, Masliah E, Campbell IL (1998) Late-onset chronic inflammatory encephalopathy in immune-competent and severe combined immune-deficient (SCID) mice with astrocyte-targeted expression of tumor necrosis factor. Am J Pathol 153:767-783.

Tani M, Fuentes ME, Peterson JW, Trapp BD, Durham SK, Loy JK, Bravo R, Ransohoff RM, Lira SA (1996) Neutrophil infiltration, glial reaction, and neurological disease in transgenic mice expressing the chemokine $\mathrm{N} 51 / \mathrm{KC}$ in oligodendrocytes. J Clin Invest 98:529-539.

Tateda K, Moore TA, Newstead MW, Tsai WC, Zeng X, Deng JC, Chen G, Reddy R, Yamaguchi K, Standiford TJ (2001) Chemokine-dependent neutrophil recruitment in a murine model of Legionella pneumonia: potential role of neutrophils as immunoregulatory cells. Infect Immun 69:2017-2024

Tessier PA, Naccache PH, Clark-Lewis I, Gladue RP, Neote KS, McColl SR (1997) Chemokine networks in vivo: involvement of C-X-C and C-C chemokines in neutrophil extravasation in vivo in response to TNF- $\alpha$. J Immunol 159:3595-3602.

Warnick RE, Fike JR, Chan PH, Anderson DK, Ross GY, Gutin PH (1995) Measurement of vascular permeability in spinal cord using Evans Blue spectrophotometry and correction for turbidity. J Neurosci Methods 58:167-171.

Wingren AG, Bjorkdahl O, Labuda T, Bjork L, Andersson U, Gullberg U, Hedlund G, Sjogren HO, Kalland T, Widegren B, Dohlsten M (1996) Fusion of a signal sequence to the interleukin-1 beta gene directs the protein from cytoplasmic accumulation to extracellular release. Cell Immunol 169:226-237.

Yang GY, Liu XH, Kadoya C, Zhao YJ, Mao Y, Davidson BL, Betz AL (1998) Attenuation of ischemic inflammatory response in mouse brain using an adenoviral vector to induce overexpression of interleukin-1 receptor antagonist. J Cereb Blood Flow Metab 18:840-847. 